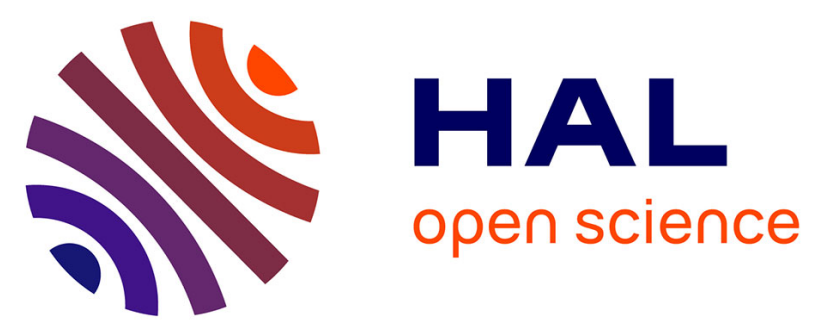

\title{
Hydrogen enriched syngas production via gasification of biofuels pellets/powders blended from olive mill solid wastes and pine sawdust under different water steam/nitrogen atmospheres
}

\author{
Marwa Zribi, Marzouk Lajili, Francisco Javier Escudero Sanz
}

\section{To cite this version:}

Marwa Zribi, Marzouk Lajili, Francisco Javier Escudero Sanz. Hydrogen enriched syngas production via gasification of biofuels pellets/powders blended from olive mill solid wastes and pine sawdust under different water steam/nitrogen atmospheres: Review. International Journal of Hydrogen Energy, 2019, 44 (22), pp.11280-11288. 10.1016/j.ijhydene.2018.10.021 . hal-01936756

\section{HAL Id: hal-01936756 \\ https://imt-mines-albi.hal.science/hal-01936756}

Submitted on 27 Nov 2018

HAL is a multi-disciplinary open access archive for the deposit and dissemination of scientific research documents, whether they are published or not. The documents may come from teaching and research institutions in France or abroad, or from public or private research centers.
L'archive ouverte pluridisciplinaire HAL, est destinée au dépôt et à la diffusion de documents scientifiques de niveau recherche, publiés ou non, émanant des établissements d'enseignement et de recherche français ou étrangers, des laboratoires publics ou privés. 


\title{
Hydrogen enriched syngas production via gasification of biofuels pellets/powders blended from olive mill solid wastes and pine sawdust under different water steam/nitrogen atmospheres
}

\author{
M. Zribi ${ }^{a}$, M. Lajili ${ }^{a, *}$, F.J. Escudero-Sanz ${ }^{b}$ \\ a UR: EMIR (Etude des Milieux Ionisés et Réactifs), 15 Avenue Ibn Eljazzar IPEIM, Monastir, 5019, Tunisia \\ ${ }^{\mathrm{b}}$ RAPSODEE (UMR CNRS 5302)IMT Mines-AlbiCampus Jarlard, 81013, Albi CT Cédex9, France
}

\author{
Keywords: \\ Biomass \\ Pyrolysis \\ Gasification \\ Syngas \\ Rate of conversion \\ Char reactivity
}

\section{A B S T R A C T}

In this work, we study the gasification of pellets produced, after densification, by blending olive mill solid wastes, impregnated or not by olive mill waste water, and pine sawdust under different steam/nitrogen atmospheres. The charcoals necessary for the gasification tests were prepared by pyrolysis using a fixed bed reactor. The gasification technique using steam was chosen in order to produce a hydrogen-enriched syngas. Gasification tests were performed using macrothermogravimetric equipment. Tests were carried out at different temperatures $\left(750{ }^{\circ} \mathrm{C}\right.$, $800^{\circ} \mathrm{C}, 820^{\circ} \mathrm{C}, 850^{\circ} \mathrm{C}$ and $900^{\circ} \mathrm{C}$ ), and at different atmospheres composed by nitrogen and steam at different percentages $(10 \%, 20 \%$ and $30 \%)$. Results show that the mass variation profiles is similar to the usual lingo-cellulosic gasification process. Moreover, the increase of temperatures or water steam partial pressures affects positively the rate of conversion and the char reactivity by accelerating the gasification process. The increase of the gasification yields demonstrates the promise of using olive mill by-products as alternative biofuels ( $\mathrm{H}_{2}$ enriched syngas).

\section{Introduction}

Energy supply represents a major challenge facing our planet today. In particular, the transition from fossil resources into sustainable and renewable ones becomes is becoming a pressing issue [1-4]. This transition is justified by greenhouse gas and other pollutants emissions which affect seriously human health and climate change [5]. For this reason biomass feedstocks have emerged in last decade as a promising renewable energy source and, thereby, received a particular attention due to their high availability worldwide [6]. Biomass can be utilized through three routes: physicochemical (e.g. the production of vegetable oils from seeds of oil plants using two/ three phases trituration), biochemical (e.g. fermentation and hydrolysis of sugar plants, anaerobic digestion of wet biomass, etc.) and thermochemical (e.g. torrefaction, pyrolysis, combustion and gasification) [7,8]. Pyrolysis and gasification processes have emerged as suitable paths for producing alternative solid, liquid and gaseous biofuels. Especially, alternative gaseous biofuels, called syngas, can be obtained through biomass gasification with steam and/or carbon dioxide [9-12]. This trend was accelerated by huge demands on hydrogen and

\footnotetext{
* Corresponding author.

E-mail address: marzouk.lajili@ipeim.rnu.tn (M. Lajili).
} 
syngas in new industriel applications. In fact, syngas has proved to be a promising route in chemical, oil and energy due to its wide applications. This gas can be used as a feedstock for the production of hydrogen, ammonia, methanol and FicherTropsch products [13]. Moreover, it can be considered as a fuel for gas turbine plants used for electricity generation [14], or as a fuel cell for mobile sources (e.g. cars) [15]. It can also play the role of an electricity supplier through solid oxide fuel cells [13]. Finally it can be exploited as a primary fuel [16].

All this richness of the syngas comes from its composition. Indeed, recent investigations on biomass show that syngas includes $\mathrm{H}_{2}, \mathrm{CO}, \mathrm{CO}_{2}, \mathrm{CH}_{4}, \mathrm{H}_{2} \mathrm{O}$ in different proportions depending on the biomass, and also on the conditions in which the syngas is produced, such as temperature, pressure, residence time and the gasifier agent [17-19]. $\mathrm{H}_{2}$ and $\mathrm{CO}$ are the major components of interest here since they could be converted to alternative synthetic biofuel through various processes such as the Ficher-Tropsch reaction [20]. Moreover, the combustion of the syngas is relatively clean by comparison to fossil fuels. Hence, this combustion is presents many advantages such as the decrease of particulate matter (PMs) which can be deposed easely on human airways causing serious respiratory problems as is was modelled and simulated in Ref. [21]. Several investigations have studied the char gasification under different atmospheres [22-25]. Also, it was reported in the literature that the char textural properties are clearly correlated to gasification rate [26]. Moreover, it was reported that the calorific value of the produced gas depends on the gasifier agent. Indeed, it is well known that air gasification produces a poor quality of syngas in terms of heating value (a higher heating value, $\mathrm{HHV}$, of around $4-7 \mathrm{MJ} / \mathrm{Nm}^{3}$ ); whereas, using pure oxygen or water steam as gasifier agent leads to a higher quality of syngas (around 10-18 MJ/ $\mathrm{Nm}^{3}$, HHV) $[5,14,27,28]$.

In this study, the charcoal was prepared using slow pyrolysis under an inert atmosphere in a horizontal fixed bed furnace. After that, we carried out gasification tests using a macro-TG at various atmospheres composed of a mixture of $\mathrm{N}_{2}$ and water steam with a given partial pressure and under a given isothermal temperature. We focused on the effect of the partial pressure variation and temperature variation on the conversion; the rate of conversion and the char reactivity respectively.

\section{Experimental device}

\section{Samples and preparation}

The olive mill wastes used in this work were collected from the Zouila oil Press Company situated in Mahdia in Tunisia, while, the pine sawdust was provided from a wood factory situated in Tunisia. Samples were prepared as it was reported in our previous work [29]. First we carry out a densification of the raw materials (olive mill solid waste (OMSW) with and without impregnation by olive mill wastewater (OMWW), and with and without mixing with pine sawdust (PS)) to obtain the pellets. Hence, 4 samples types were prepared:

- PS100: composed of $100 \%$ pine sawdust.

- PS-OMWW: composed of $50 \%$ pine sawdust and $50 \%$ olive mill wastewater.
- EOMSW-OMWW: composed of 50\% exhausted olive mill solid waste and $50 \%$ olive mill wastewater.

- EOMSW100: composed of $100 \%$ olive mill solid waste.

In order to study the influence of particle sizing during gasification, the charcoals obtained after the slow pyrolysis process were crushed and then sieved for obtaining a powder composed by particles of less than $100 \mu \mathrm{m}$ size.

\section{Samples characterization}

The moisture content of the different samples was determined using a stove at $105^{\circ} \mathrm{C}$ during a period of $24 \mathrm{~h}$ according to the EN 14774 standard, and by using a scale precisa XT220A for weighing the mass of sample before and after moisture evaporation. The ash content was determined using a muffle furnace in which the temperature is fixed at $900{ }^{\circ} \mathrm{C}$ during $1.5 \mathrm{~h}$ according to the DIN 51719 standard.

The high heating value (HHV) was determined using a calometric bomb calorimeter IKAC200 according to the EN 14918 standard. Then, the low heating value (LHV) is deduced from the HHV according to:

$L H V=H H V-L_{V}\left(9 \frac{\% H}{100} \times\left(1-\frac{\% H u}{100}\right)+\frac{\% H u}{100}\right)$

Both LHV and HHV are expressed in (MJ.kg $\left.{ }^{-1}\right), L_{V}$ is the latent heat of vaporization (approximately $2502 \mathrm{~kJ} \mathrm{~kg}^{-1}$ ), \% $\mathrm{H}$ is the hydrogen percentage and \% $\mathrm{Hu}$ is the moisture ratio.

The bulk densities of the different samples were also determined by calculating the ratio of the mass and the volume of the container conformingly to the CENTS15103 standard method. The energy density is a crucial parameter characterizing the solid biofuels. It is obtained by multiplying the LHV and the bulk density [29].

The mineral analysis shows that the potassium (K), the calcium (Ca) and the sodium ( $\mathrm{Na}$ ) are the main elements present in the different prepared samples.

\section{Experimental device}

Gasification, as an intricate process, makes impossible to control and optimize its several overlapping steps separately. Hence, to improve the gasification efficiency and the char transformation rate, gasification should be performed in the absence of the volatiles [30]. For this reason, a preliminary slow pyrolysis process was investigated under inert atmospheres using a horizontal fixed bed reactor in order to produce the char. Then, the gasification tests of prepared samples (pellets and powders) were assessed in a Macrothermogravimetric (M-TG) reactor which was previously described with precision [4]. Indeed, the M-TG device is mainly formed by three parts: (1) the heating system composed by a liquid water evaporator, a gas pre-heater and an alumina cylindrical reactor heated electrically, (2) a gas flow control system allowing gas mixture for varying the gasification atmosphere composition, (3) a weighing system including an electronic balance $( \pm 0.1 \mathrm{mg})$ and a stand with a platinum basket. The cylindrical reactor is $2 \mathrm{~m}$ long and $0.75 \mathrm{~m}$ internal diameter. Before injection into the reaction zones, the different mixtures of gas should be pre-heated to the chosen 
reaction temperature. The metallic stand placed over the electronic scale is equipped with three ceramic hollow tubes with $1 \mathrm{~m}$ length and $2.4 \mathrm{~mm}$ external diameter. These tubes end with a platinum basket of $50 \mathrm{~mm}$ diameter, a solid bottom and a side wall made from a $0.5 \mathrm{~mm}$ grid in order to allow the gas to pass through it. The totality of the weighing system can be moved in the vertical direction using a crank handle. A special attention should be paid to introduce the sample inside the reactor hot zone within 13-15 s. Hence, these conditions of very fast heating (about $100{ }^{\circ} \mathrm{C} / \mathrm{s}$ ) are close to the fluidized bed rectors' conditions. The average speed of the fluid inside the reactor was approximately $0.2 \mathrm{~m} / \mathrm{s}$ in order to avoid any turbulent regime and the nitrogen volume flow rate was fixed at $6 \mathrm{NL} / \mathrm{min}$. The mass loss was recorded using a MSE524S scale and an in-house Lab-View code. The related data to the sample entrance in the furnace were rejected in order to avoid the buoyancy forces' effect via a preliminary blank test. For achieving our study, some parameters characterizing the gasification process were defined:

- The characteristic time of gasification $\tau_{\mathrm{G}}$ corresponding to the needed time to reach $97 \%$ of char conversion according to the following expression:

$\tau_{G}=t_{X=97 \%}-t_{X=0 \%}$

- The char reactivity which represents the rate of char consumption divided by an extensive properly, namely the char mass. This parameter is expressed by:

$R_{\mathrm{t}}=\left[1 /\left(1-X_{\mathrm{t}}\right)\right] \times\left[d \mathrm{X}_{\mathrm{t}} / d \mathrm{t}\right]$

where, $\mathrm{X}$ is the conversion of char during the gasification:

$X_{\mathrm{t}}=\left(m_{0}-m_{\mathrm{t}}\right) /\left(m_{0}-m_{\text {ash }}\right)$

$\mathrm{m}_{0}, \mathrm{~m}_{\mathrm{t}}$ and $\mathrm{m}_{\text {ash }}$ are the initial mass of char, the mass at a time $t$ and the mass of the residual ash respectively.

- The rate of conversion defined as:

$v_{\mathrm{G}}=d \mathrm{X}_{\mathrm{t}} / \mathrm{dt}$

\section{Results and discussions}

\section{Samples characterization}

The energy contents, the ultimate and the proximate analyses of the different samples are summarized in Table 1. A
Comparison with other available biomasses reported in the literature is carried out. This comparison shows that the prepared samples follow typical compositions [1,2]. Indeed, we notice that the OW is characterised by its relatively high ash content (5.20\%); whereas, the PS ash content is relatively small $(<0.30 \%)$. Moreover, the prepared pellets generate a high percentage of volatiles. More precisely, the PS pellets are richer of volatiles than the OW pellets $(73.95 \%$ for OW versus $84.20 \%$ for PS). Finally, both OW and PS samples present considerable contents of fixed carbon; $17.62 \%$ and $15.40 \%$ respectively.

Consigned results in Table 1 show that the OW pellets have more carbon content than the PS pellets. However, the oxygen content of the PS pellets is higher than that of the OW pellets. The nitrogen content is significant only for OW pellets; while, the sulphur contents can be neglected for both pellets types. Hence, a non-negligible amounts of $\mathrm{NO}_{\mathrm{x}}\left(\mathrm{NO}+\mathrm{NO}_{2}\right)$ can be expected during the combustion of the OW pellets. In contrast, given the very small sulphur contents $(<0.1) \mathrm{SO}_{\mathrm{x}}$ emissions are expected to be insignificant [29].

Table 2 shows that inorganic elements ( $\mathrm{Na}, \mathrm{K}$ and $\mathrm{Ca}$ ) are highly concentrated in the EOMSW, EOMSW-OMWW and PSOMWW samples. This elevated concentration is not only due to the initial amount of $\mathrm{Na}, \mathrm{K}$ and $\mathrm{Ca}$ in raw material EOMSW but also due to impregnation process when using OMWW (rich of these minerals) [30,31]. It is worth noting that these higher inorganic contents are very interesting of point of view catalytic effect during gasification process [31-33].

\section{Effects of the variation of the $\mathrm{H}_{2} \mathrm{O}$ partial pressure and the temperature on the conversion}

The gasification is a thermochemical conversion process occurring at relatively elevated temperature, up to $1400^{\circ} \mathrm{C}$ in some cases [32-34]. Materials which are subject to this process are solid carbonaceous fuels such as coal and biomasses in the presence of a gasifier agent such as air, oxygen, steam and/or carbon dioxide. This gasifier agent is injected in small concentrations with an inert gas such as nitrogen $\left(\mathrm{N}_{2}\right)$. The gasification yields consist of a biogas, tars (liquids from condensable vapours) and remaining biochar (solid). The main product of gasification is a mixture of gases, called syngas which is mainly composed of $\mathrm{CO}, \mathrm{H}_{2}, \mathrm{CO} 2, \mathrm{CH}_{4}$ and volatile organic compounds $\mathrm{C}_{2-4} \mathrm{H}_{\mathrm{x}}$ and tars.

After studying the gasification of the 4 different samples at different temperatures and for different percentages of steam, results show that the conversion curves $X=f(t)$ follow the usual behaviour during the thermal degradation of lingocellulosic materials as it is illustrated on Fig. 1 and Fig. 2. Moreover, we found that, when increasing the partial pressure

\begin{tabular}{|c|c|c|c|c|c|c|c|c|c|c|c|c|}
\hline \multirow[t]{2}{*}{ Samples } & \multicolumn{4}{|c|}{ Proximate analysis } & \multirow[t]{2}{*}{ LHV } & \multirow[t]{2}{*}{$\mathrm{BD}$} & \multirow[t]{2}{*}{ ED } & \multicolumn{5}{|c|}{ Ultimate analysis } \\
\hline & \%Hu (W.b.) & \%VM (d.b.) & \%FC (d.b.) & \%Ash (d.b.) & & & & $\% \mathrm{C}$ & $\% \mathrm{H}$ & $\% \mathrm{O}$ & $\% \mathrm{~N}$ & $\% \mathrm{~S}$ \\
\hline OW100 & 38.34 & 73.95 & 17.62 & 8.43 & 19.23 & 920 & 17.69 & 49.50 & 5.33 & 43.81 & 1.27 & 0.09 \\
\hline PS100 & 7.90 & 84.20 & 15.40 & 0.40 & 17.80 & 693 & 12.33 & 47.17 & 6.10 & 46.27 & $<0.1$ & $<0.01$ \\
\hline
\end{tabular}

BD: The bulk density $\left(\mathrm{kg} . \mathrm{m}^{-3}\right)$; ED: The energy density (GJ.m $\left.{ }^{-3}\right)$; d.b.: on dry basis; w.b.: on wet basis 
Table 2 - Concentration of inorganic elements (g/kg d.b. basis).

\begin{tabular}{lcccc} 
Parameter & EOMSW & EOMSW-OMWW & PS & PS-OMWW \\
\hline $\mathrm{Na}$ & 0.78 & 1.79 & 0.01 & 1.15 \\
$\mathrm{~K}$ & 3.67 & 7.53 & 0.36 & 3.40 \\
$\mathrm{Ca}$ & 1.13 & 1.45 & 0.36 & 0.87 \\
\hline
\end{tabular}

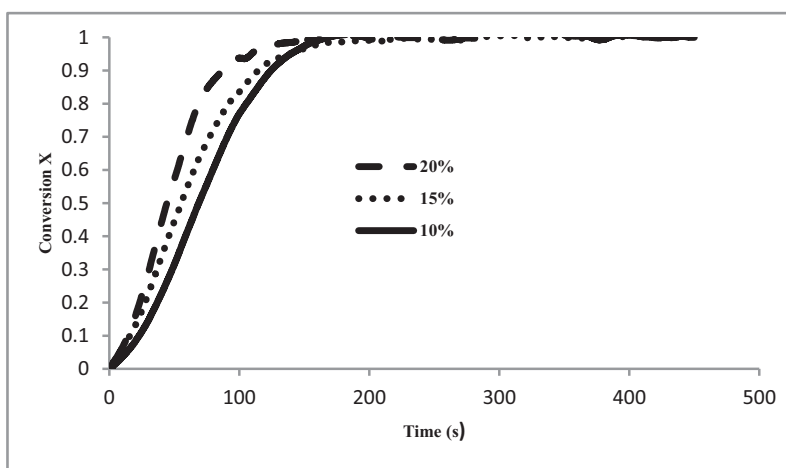

Fig. 1 - Influence of the $\mathrm{H}_{2} \mathrm{O}$ partial pressure on the temporal variation of the conversion of PS-OMWW100 under $850^{\circ} \mathrm{C}$.

of the steam, the reaction rate increases as shown in Fig. 1 in agreement with what was reported in the literature $[4,35]$. Moreover, Fig. 2 shows the char conversion evolution as a function of elapsed time at $20 \% \mathrm{H}_{2} \mathrm{O}_{\mathrm{v}}$ and for five different temperatures; $750^{\circ} \mathrm{C}, 800{ }^{\circ} \mathrm{C}, 820^{\circ} \mathrm{C}, 850{ }^{\circ} \mathrm{C}$ and $900{ }^{\circ} \mathrm{C}$ respectively. It can be seen that an increase in temperature from 750 to $900{ }^{\circ} \mathrm{C}$ yields an increase in the rate of char conversion and consequently to a decrease of the characteristic time of gasification [4]. More precisely, in Fig. 1 a conversion level of 90\% was reached respectively after 90, 130 and $150 \mathrm{~s}$ with steam concentrations of $20 \%, 15 \%$ and $10 \%$ respectively. These values of the characteristic time of gasification are different to values obtained by Guizani et al. [4] which are higher (330s and $580 \mathrm{~s}$ for $20 \%$ and $10 \% \mathrm{H}_{2} \mathrm{O}$ respectively). This

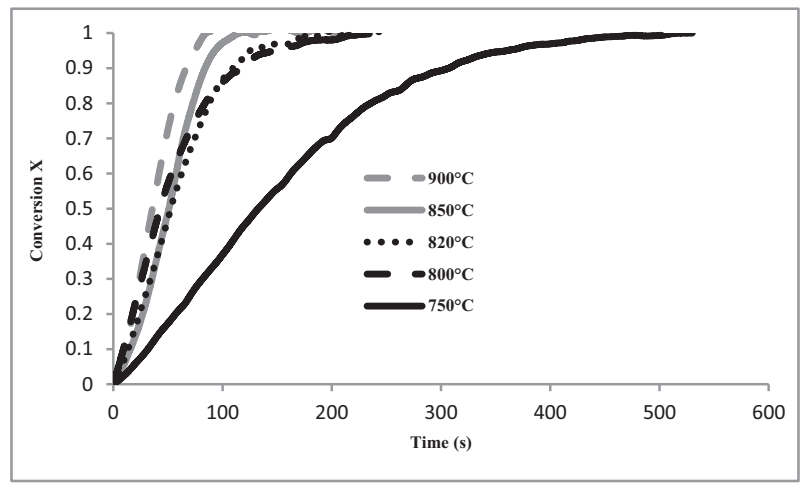

Fig. 2 - Influence of the variation of the temperature on the temporal variation of the conversion of EOMSW-OMWW under $20 \% \mathrm{H}_{2} \mathrm{O}_{\mathrm{v}}$.

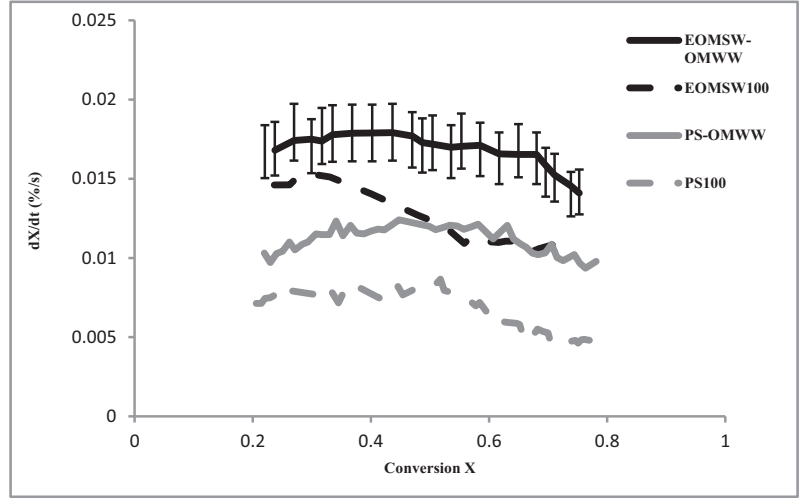

Fig. 3 - Rate of Conversion evolution as a function of the conversion of the different samples at $900{ }^{\circ} \mathrm{C}$ and under $20 \% \mathrm{H}_{2} \mathrm{O}_{\mathrm{v}}$.

is discrepancy is expected since the chars are different (beech wood chips for Guizani et al. [4]) and also the techniques with which the char were prepared were different (high-heating rate chars for them and low-heating rate for us).

Influence of the samples types on the rate of conversion and the char reactivity

The rate of conversion $d X / d t$ is a gasification characteristic which is always considered as a preliminary indicator of the material reactivity. Fig. 3 shows the conversion rate $d X / d t$, as functions of $X$ for different samples. The results show that rates of conversion evolving as function of the conversion $(X)$ depend strongly on the samples type. Indeed, we observe that at $900{ }^{\circ} \mathrm{C}$ and at $20 \% \mathrm{H}_{2} \mathrm{O}_{\mathrm{v}}$ conditions, the EOMSW100 exhibits a greater reactivity than PS100. Moreover, the addition of the OMWW for each sample enhances its reactivity, perhaps due to its richness in inorganic matter (K, Ca and $\mathrm{Na}$ ) [36]. Thus, the maximum rate of mass loss corresponds to EOMSWOMWW; while the lowest value is attributed to 100PS (Figs. 3, and Fig. 4).

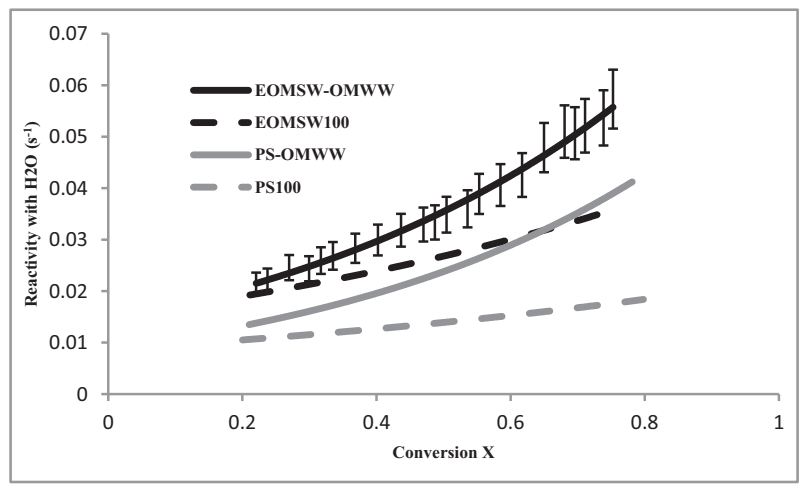

Fig. 4 - The char reactivity variation as a function of the conversion of the different samples realized at $900{ }^{\circ} \mathrm{C}$ and under $20 \% \mathrm{H}_{2} \mathrm{O}_{v}$. 


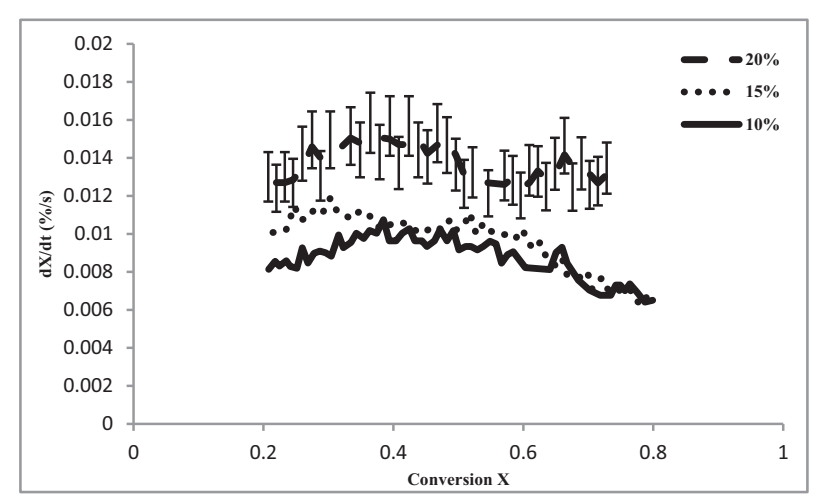

Fig. 5 - Influence of the partial pressure water steam on the rate of conversion as function of the conversion at $850{ }^{\circ} \mathrm{C}$ for PS-OMWW sample.

Influence of the variation of the steam water partial pressure and the temperature on the rate of conversion and the char reactivity

Fig. 5 and Fig. 6 show respectively, the influence of the partial pressure of the water steam on the rate of conversion and also, on the char reactivity as a function of the conversion (X) at $850^{\circ} \mathrm{C}$ for the PS-OMWW sample. We observed that the char reactivity increases with a higher percentage of steam from 10 to $20 \%$ in agreement with results stated by Guizani et al. [37]. Moreover, we notice that each curve presents two stages: in the left side zone corresponding to $\mathrm{X}<0.5$ the rate of conversion increases slightly; whereas, in the right side zone for $\mathrm{X}>0.5$ the rate of conversion presents a quite decrease. This result is may be due to the kinetic of the reactions which is affected not only by the nature of the gasifier agent and its partial pressure, but also, by the heat flux interaction between the gas flow and the sample, and perhaps by the degree level of the conversion $(X)$. These observations are consolidated by Fig. 6, but in this case, the char gasification reactivity is in a continuous increase. However, as we can see, the rate of conversion and the char gasification reactivity become quite

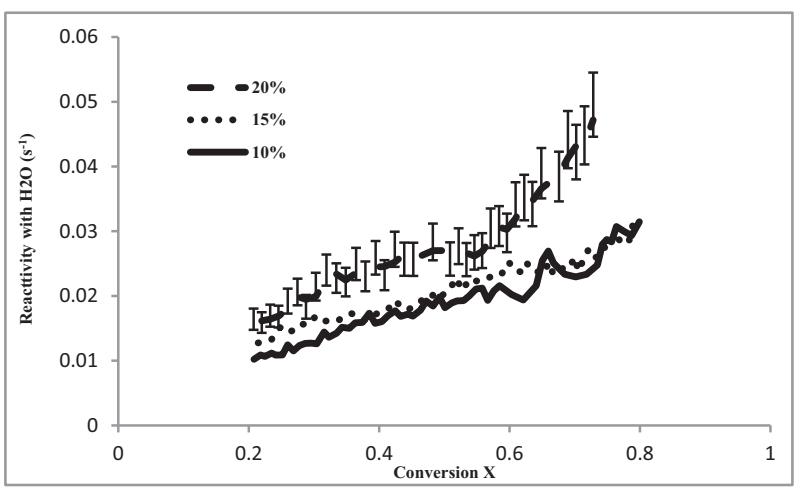

Fig. 6 - Influence of the partial pressure water steam on the char gasification reactivity as a function of the conversion at $850^{\circ} \mathrm{C}$ for PS-OMWW sample.

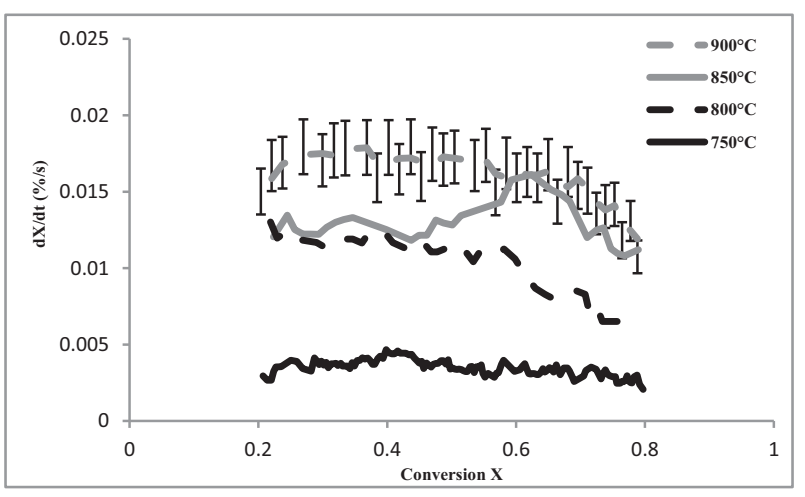

Fig. 7 - Influence of the variation of temperature on the rate of conversion. under $20 \% \mathrm{H}_{2} \mathrm{O}$ for EOMSW-OMWW.

higher for $10 \%$ water steam than for $15 \%$ water steam and this for $\mathrm{X}>0.6$.

Fig. 7 and Fig. 8 show the evolution of the rate of conversion and the char gasification reactivity as a function of $\mathrm{X}$, and for 5 fixed temperatures $\left(750,800,820,850\right.$ and $\left.900^{\circ} \mathrm{C}\right)$. We conclude that the samples become more reactive with higher temperature in agreement with what was reported in the literature $[37,38]$.

Influence of the samples' properties on the gasification reactivity

Table 3 shows the characteristic times of gasification and rates during the gasification stage for the four samples when working at the same temperature $850^{\circ} \mathrm{C}$ and under the same steam percentage $20 \%$. The characteristic time $\tau_{G}$ corresponds to the time needed to reach $97 \%$ of char conversion is calculated using the following expression:

$\tau_{G}=t_{X=97 \%}-t_{X=0 \%}$

Moreover, Fig. 9 displays the influence of the samples' types on the gasification reactivity as a function of elapsed time.

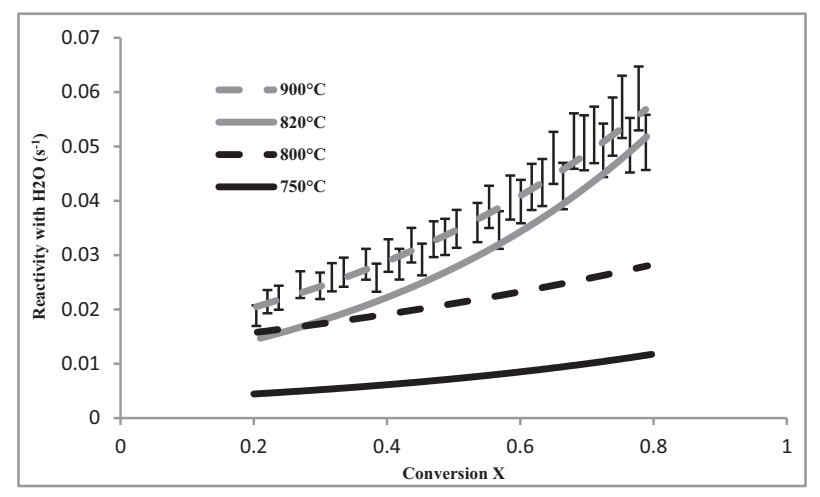

Fig. 8 - Influence of the temperature on the char gasification reactivity as a function of the conversion under $20 \% \mathrm{H}_{2} \mathrm{O}$ for the EOMSW-OMWW sample. 
Table 3 - Determination of the time characteristic and the rate of gasification of the 4 samples, at the same

temperature $850^{\circ} \mathrm{C}$ and the same water steam percentage $20 \%$.

\begin{tabular}{lcccc} 
Sample & $\begin{array}{c}\text { EOMSW } \\
100\end{array}$ & $\begin{array}{c}\text { EOMSW- } \\
\text { OMWW }\end{array}$ & PS-OMWW & PS100 \\
\hline$\tau_{\mathrm{G}}(\mathrm{s})$ & 103 & 99 & 197 & 197 \\
$U_{\mathrm{G}}\left(10^{-3} \mathrm{~s}^{-1}\right)$ & 9.42 & 9.80 & 7.89 & 4.92 \\
\hline
\end{tabular}

The conversion function $X$, and more precisely in the region presenting the highest gradient of variation, is usually considered as a preliminary indicator of the material reactivity. At $850{ }^{\circ} \mathrm{C}$, the lowest rate of conversion is exhibited by the PS100 sample as it is illustrated in Fig. 9 and confirmed in Table 3 (the characteristic time is approximately $4.9210^{-3} \mathrm{~s}^{-1}$ ), while the highest one is obtained by EOMSW-OMWW powder (approximately $9.80 \quad 10^{-3} \mathrm{~s}^{-1}$ ). However, we notice that these values are higher than those reported in the literature under the same experimental conditions [39]. Indeed, in agreement with many published results in the literature, the blended and impregnated samples experience the highest gasification rates thanks to the mineral contents supplied by the OMWW as it is shown in Table $2[4,11,26,32,39-41]$.

Influence of temperature and steam molar fraction on the characteristic time and gasification rate of EOMSW-OMWW

The gasification of the char of EOMSW-OMWW under the powder state (particles sizes are less than $100 \mu \mathrm{m}$ ) was studied at three different temperatures; $800^{\circ} \mathrm{C}, 820^{\circ} \mathrm{C}$ and $850^{\circ} \mathrm{C}$, and under different steam molar fraction; $10 \%, 15 \%$ and $20 \%$ respectively. Table 4 summarizes the characteristic gasification times and the gasification rates for the different temperatures and steam percentages.

We observe in Table 4 that the characteristic times of the EOMSW-OMWW gasification are $202 \mathrm{~s}, 195 \mathrm{~s}, 115 \mathrm{~s}$ at $800^{\circ} \mathrm{C}$, $820^{\circ} \mathrm{C}$, and $850^{\circ} \mathrm{C}$ respectively when the steam percentage is $10 \%$. Therefore, as indicated earlier, the reactivity increases with an increased temperature. We also note that the steam partial pressures affect positively the samples' reactivity.

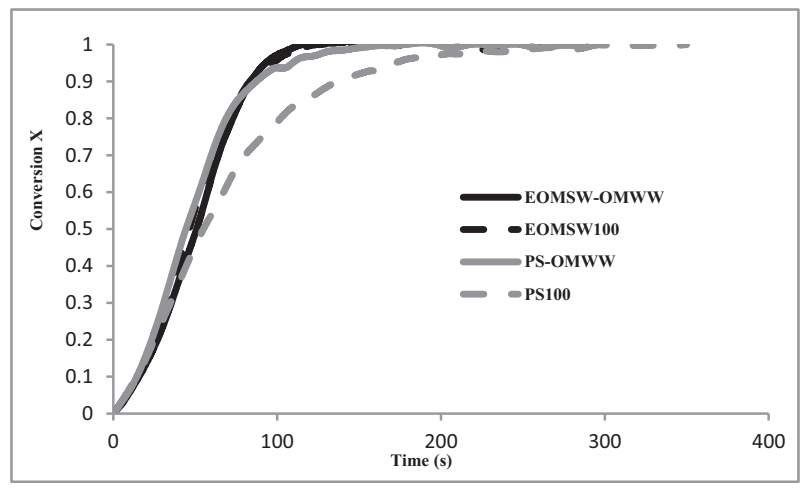

Fig. 9 - Comparison between the temporal evolutions of the conversion of the four samples under $20 \%$ water steam composition and at $850^{\circ} \mathrm{C}$.
Table 4 - The characteristic time and the gasification rate of the EOMSW-OMWW at different temperatures.

\begin{tabular}{lccc} 
Temperature & $\mathrm{H}_{2} \mathrm{O}$ percentage & $\tau_{\mathrm{G}}(\mathrm{s})$ & $\mathrm{U}_{\mathrm{G}}\left(10^{-3} \mathrm{~s}^{-1}\right)$ \\
\hline $800{ }^{\circ} \mathrm{C}$ & $10 \%$ & 202 & 4.80 \\
& $15 \%$ & 182 & 5.33 \\
& $20 \%$ & 172 & 5.64 \\
$820{ }^{\circ} \mathrm{C}$ & $10 \%$ & 195 & 4.97 \\
& $20 \%$ & 162 & 5.99 \\
$850{ }^{\circ} \mathrm{C}$ & $10 \%$ & 115 & 8.43 \\
& $15 \%$ & 113 & 8.58 \\
& $20 \%$ & 99 & 9.80 \\
\hline
\end{tabular}

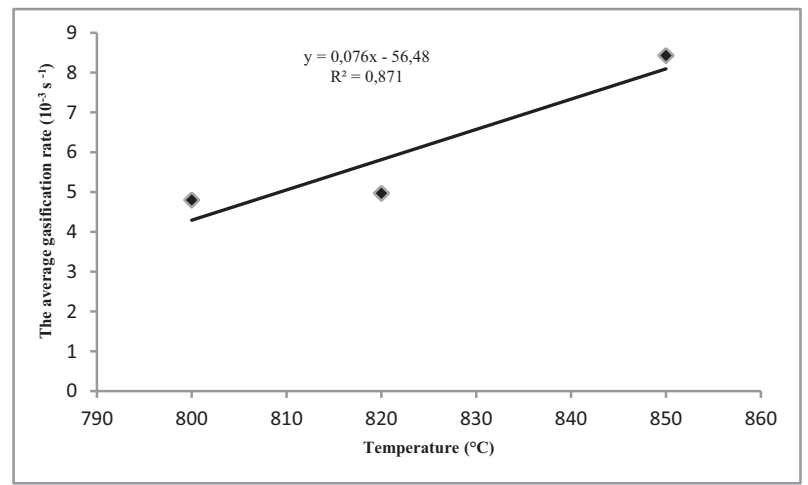

Fig. 10 - Evolution of the average gasification rate of EOMSW-OMWW as a function of the temperature.

Indeed, at $800{ }^{\circ} \mathrm{C}$ the characteristic times are $202 \mathrm{~s}, 182 \mathrm{~s}$, $172 \mathrm{~s}$ at $10 \%, 15 \%$ and $20 \%$ respectively. Note that under similar experimental conditions, Guizani et al. [10] show that for a conversion (X) of $90 \%$, and at a temperature of $900^{\circ} \mathrm{C}$, the gasification rate of beech wood chips is approximately $1510^{-3}$ $\mathrm{s}^{-1}$. However, our obtained values are lower than those found by Guizani et al. [10], but higher than those reported by Lajili et al. [39].

The average gasification rate is defined as the mean gasification rate. More precisely it is calculated as the average

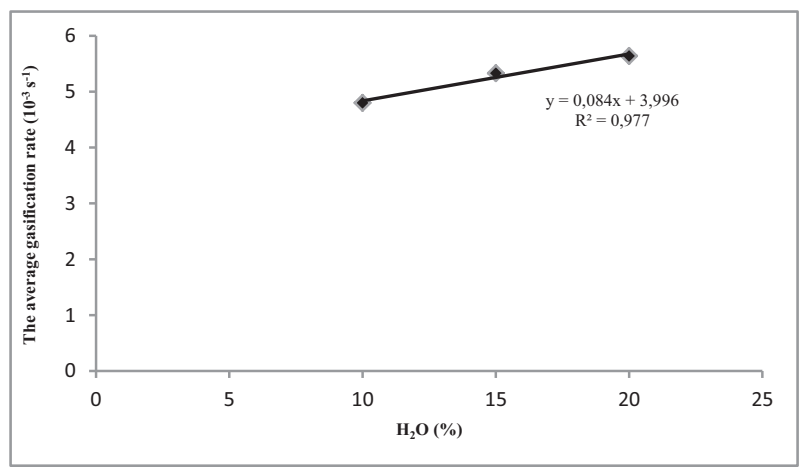

Fig. 11 - Evolution of the average gasification rate of EOMSW-OMWW as a function of the steam partial pressure. 
Table 5 - The characteristic times and the gasification rates of the different samples in powder and pellet states at $850{ }^{\circ} \mathrm{C}$ and under $20 \%$ water steam molar fraction.

\begin{tabular}{|c|c|c|c|c|c|c|c|}
\hline \multicolumn{4}{|c|}{ Powder form } & \multicolumn{4}{|c|}{ Pellets form } \\
\hline & EOMSW100 & EOMSW-OMWW & PS-OMWW & & EOMSW100 & EOMSW-OMWW & PS-OMWW \\
\hline$\tau_{\mathrm{G}}(\mathrm{s})$ & 103 & 99 & 123 & $\tau G(s)$ & 830 & 755 & 666 \\
\hline$U_{G}\left(10^{-3} s^{-1}\right)$ & 9.42 & 9.80 & 7.89 & $v G\left(10^{-3} \mathrm{~s}^{-1}\right)$ & 1.21 & 1.33 & 1.50 \\
\hline
\end{tabular}

value of the conversion rate through the char conversion range $(X=0 \%-X=95 \%)$. Fig. 10 and Fig. 11 show the average gasification rate evolution as a function of temperature and steam molar fraction respectively.

Fig. 10 shows that the average gasification rate increases from $4.80 .10^{-3} \mathrm{~s}^{-1}$ to $8.43 .10^{-3} \mathrm{~s}^{-1}$ for a steam fraction of $10 \%$ when we increase the temperature from $800{ }^{\circ} \mathrm{C}$ to $850{ }^{\circ} \mathrm{C}$. At $850{ }^{\circ} \mathrm{C}$ and $10 \% \mathrm{H}_{2} \mathrm{O}_{\mathrm{v}}$, our values are about twice higher than those performed by Nilsson et al. [42]. Fig. 11 shows that the mean gasification rate increases from $4.80 .10^{-3} \mathrm{~s}^{-1}$ to 5.64.10 $0^{-3} \mathrm{~s}^{-1}$ at $800{ }^{\circ} \mathrm{C}$ when we increase the steam molar fraction from $10 \%$ to $20 \%$. However, according to Lajili et al. [39], the average gasification rate is four times lower than what we find in this work, while the characteristic time of gasification is much higher $\left(755 \mathrm{~s}\right.$ at $850^{\circ} \mathrm{C}$ and $20 \% \mathrm{H}_{2} \mathrm{O}$ for the pellets of impregnated exhausted olive mill solid waste). We can conclude that the powder form enhances the sample's gasification reactivity.

\section{Comparison between the pellets and the powder during gasification}

In this section, we focus on the comparison of the gasification of the powder samples and the pellets samples when they are treated under the same experimental conditions of $20 \%$ steam molar fraction and $850^{\circ} \mathrm{C}$.

Table 5 shows the characteristic times and the gasification rates for the different samples in powder and pellet states respectively.

We can see that for all samples, the characteristic time of gasification is shorter and the gasification rate is higher for powders than for pellets. Also, the rate of gasification is higher for powders than for pellets. Indeed, as it was stated by S. Luo et al. [43], this effect can be explained by the increase of the surface area of the small particles interacting with the gasifier agent (steam) and by the formation of volatile products that leave the sample without undergoing secondary cracking reactions. At the contrary, for the larger particles, this phenomenon could be dominant, leading to a more char and tar formation. Hence, mass and heat limitations are more significant for larger particles. In our case these physical phenomena are more accentuated due the big difference in size between pellets and powder. Moreover, it was reported by Inayat et al. [44] that smaller particle size of blended biomass prepared from wood chips (acacia mangium) and coconut shells (Cocos nucifera L) leads to higher hydrogen, carbon monoxide and methane concentrations in syngas. High peak concentrations were clearly observed with the 5-10 mm particles; whereas the concentrations decrease with the big particle size $(25-50 \mathrm{~mm})$. Besides, Y. Feng et al. [45] have studied the influence of particle size and temperature on gasification performance. They concluded that when increasing the particle size from 0.125 to $0.250 \mathrm{~mm}$, the $\mathrm{CO}$ and $\mathrm{H}_{2}$ concentrations were decreased, while the contents of $\mathrm{CO}_{2}$ and $\mathrm{CH}_{4}$ were increased. This result can be explained by the fact that when the particle size decreased, the reactions are mainly controlled by pyrolysis and gasification, whereas when the particle size increased the reactions are mainly governed by the diffusion process. Consequently, the size of particle influences seriously the gas diffusion speed. Finally, the smaller particle size is expected to be more advantageous to produce high quality gas. Moreover, we observe that for the powder form the highest rate of gasification is exhibited by EOMSW-OMWW $\left(9.8010^{-3} \mathrm{~s}^{-1}\right)$ with a characteristic time of $99 \mathrm{~s}$ followed by EOMSW100 $\left(9.4210^{-3} \mathrm{~s}^{-1}\right)$, PS-OMWW (7.89 $\left.10^{-3} \mathrm{~s}^{-1}\right)$ and PS100 $\left(4.9210^{-3} \mathrm{~s}^{-1}\right)$ respectively. Such behaviour can be attributed to the richness of the impregnated samples in inorganic matter provided by the OMWW, and especially in potassium $(\mathrm{K})$ which is known by its high catalytic effect $[4,39]$. Indeed, the Schmidt's team, when working on the effects of biomass inorganics using rhodium as catalyst, concluded that the role of the sodium and potassium, which are the main inorganic compounds in our case, was to decrease the methane conversion by $9 \%$ and $16 \%$ respectively. Furthermore, the potassium decreased the $\mathrm{H}_{2}$ and $\mathrm{CO}$ selectivity by $5 \%$ and $7 \%$ respectively [46].

In contrast, we also observe that the PS-OMWW pellet presents the highest gasification rate followed by EOMSW-OMWW and EOMSW100 respectively. Accordingly, the characteristic time for pellets exhibits the opposite trend to that of the gasification rate i.e. it decreases from EOMSW100 to EOMSWOMWW and then to PS-OMWW. These observations are in accordance with recent results reported by Lajili et al. [39]. In addition to the catalytic effect due the impregnation process, the high reactivity of the powder, by comparison to the pellets, during gasification also can be related to the low mass the high surface exchange and to the heat transfer limitation. Measured kinetics may be considered as intrinsic kinetics. Therefore, the powder form strengthens the samples' reactivity.

\section{Conclusion}

Slow pyrolysis experiments were carried out in order to prepare 4 chars from Tunisian (OMSW, OMWW and PS) biomasses. These chars were crushed and sieved in powder form in order to obtain gasification tests under different isothermal temperatures and steam molar fractions mixed with nitrogen $\left(\mathrm{N}_{2}\right)$.

The results show that the conversion, the rate of conversion and the char reactivity are enhanced by the steam partial pressure for a given temperature. Moreover, we found that the 
same three gasification variables increase with temperature for a given steam partial pressure conditions. Moreover, the EOMSW100 sample exhibits more reactivity than the PS100. However, the most important result concerns the EOMSWOMWW sample. This sample exhibits the lowest characteristic time and the highest gasification rate thanks to the effect of the OMWW impregnation. More precisely, the catalytic effect of some minerals such as $\mathrm{K}, \mathrm{Ca}$ and Na play an important role during the gasification process. We also observe that for the same samples, when they are treated in powder state, the conversion rate and the char reactivity are enhanced (the characteristic time of gasification become shorter) by comparison with the pellet form. The results of this study provide a clear motivation to further investigate the use of OMWW as a source for renewable energy and to mitigate potential environmental problems associated with their storage of disposal.

\section{Acknowledgment}

Marwa zribi would like to express her sincere gratitude to Professor Ange Nzihou the director of Mines Albi and to Professor Sylvain Salvador for receiving her in the RAPSODEE laboratory. M. Lajili is grateful to professor Echekki from N.C.U. for his help with English and for his precious comments.

\section{R E F E R E N C E S}

[1] Verma VK, Barm S, Delattin F, Laha P, Vandendeal I, Hubin A, et al. Agropellets for domestic heating boilers: standard laboratory and real life performance. Appl Energy 2012;90:17-23.

[2] Miranda J, Arranz I, Montero I, Roman S, Rojas CV, Nogales S. Characterization and combustion of olive pomace and forest residue pellets. Fuel Process Technol 2012;103:91-6.

[3] Kraiem N, Lajili M, Limousy L, Said R, Jeguirim M. Energy recovery from Tunisian agri-food wastes: evaluation of combustion performance and emissions characteristics of green pellets prepared from tomato residues and grape marc. Energy 2016;107:409-18.

[4] Guizani C, Escudero Sanz FJ, Salvador S. Effects of CO2 on biomass fast pyrolysis: reaction rate, gas yields and char reactive properties. Fuel 2014;116:310-20.

[5] Squalli J. Renewable energy, coal as a baseload power source, and greenhouse gas emissions: evidence from U.S. statelevel data. Energy 2017;127:479-88.

[6] Neri E, Cespi D, Setti L, Gombi E, Bernardi E, Vassura I, et al. Biomass residues to renewable energy: a life cycle perspective applied at a local scale. Energies 2016;9:895.

[7] McKendry P. Energy production from biomass (part 2): conversion technologies. Bioresour Technol. 2002;83:47-54.

[8] Balat M, Balat M, Kirtay E, Balat H. Main routes for thermoconversion of biomass into fuels and chemicals. Energy Convers Manag 2009;50:3147-57.

[9] D'Orazio A, Rapagnà S, Foscolo PU, Gallucci K, Nacken M, Heidenreich S, et al. Gas conditioning in $\mathrm{H} 2$ rich syngas production by biomass steam gasification: experimental comparison between three innovative ceramic filter candles. Int J Hydrogen Energy 2015;40:7282-90.

[10] Guizani C, Jeguirim M, Gadiou R, Escudero Sanz FJ, Salvador S. Biomass char gasification by $\mathrm{H}_{2} \mathrm{O}, \mathrm{CO}_{2}$ and their mixture: evolution of chemical, textural and structural properties of the chars. Energy 2016;112:133-45.

[11] Ramage PR, Agrawal R. The hydrogen economy: opportunities, costs, barriers and R\&D needs. Washington DC: National Academies Press; 2004.

[12] van Rossum G, Potic B, Kersten SRA, van Swaaij WPM. Catalytic gasification of dry and wet biomass. Catal Today 2009;145:10-8.

[13] Higman C, van der Brugt M. Gasification. 2nd ed. Burlington USA: Gulf Professional Publishing VT; 2008.

[14] Liu K, Cui Z, Fletcher TH. Coal gasification. In: Liu K, Song C, Subramani V, editors. Hydrogen and syngas production and purification technologies. NJ USA: John Wiley \& Sons Inc; 2009. p. 156-218.

[15] Giunta P, Amadeo N, Laborde M. Simulation of low temperature water gas shift reactor using the heterogeneous model/application to a pen fuel cell. J Power Sources 2006;156:489-96.

[16] Dincer I. Hydrogen and fuel cell technologies for sustainable future. Jordan J Mech Ind Eng 2008;2:1-14.

[17] D'Orazio A, Rapagn S, Foscolo PU, Gallucci K, Nacken M, Heidenreich $\mathrm{S}$, et al. Gas conditioning in $\mathrm{H}_{2}$ rich syngas production by biomass steam gasification: experimental comparison between three innovative ceramic filter candles. Int J Hydrogen Energy 2015;40:7282-90.

[18] Nzihou A, Stanmore B, Sharrock P. A review of catalysts for the gasification of biomass char, with some reference to coal. Energy 2013;58:305-17.

[19] Heidenreich S, Foscolo PU. New concepts in biomass gasification. Prog Energy Combust Sci 2015;46:72-95.

[20] Snehesh AS, Mukunda HS, Mhapatra S, Dasappa S. FischerTropsch route for the conversion of biomass to liquid fuelsTechnical and economic analysis. Energy 2017;130:182-91.

[21] Rahimi-Gorji M, Pourmehran O, Gorji-Bandpy M, Gorji TB. CFD simulation of airflow behavior and particle transport and deposition in different breathing conditions through the realistic model of human airways. J Mol Liq 2015;209:121-33.

[22] Hognon C, Dupont C, Grateau M, Delrue F. Comparison of steam gasification reactivity of algal and lignocellulosic biomass: influence of inorganic elements. Bioressour. Technol. 2014;164:347-53.

[23] Prabowo B, Umeki K, Yan M, Nakamura MR, Castaldi MJ, Yoshikawa $\mathrm{K} . \mathrm{CO}_{2}$-steam mixture for direct and indirect gasification of rice straw in a downdraft gasifier: laboratoryscale experiments and performance prediction. Appl Energy 2014;113:670-9.

[24] Kirubakaran V, Sivaramakrishnan V, Nalinic R, Sekar T, Premalatha M, Subramanian P. A review on gasification of biomass. Renew Sustain Energy Rev 2009;13:179-86.

[25] Prins MJ, Ptasinski KJ, Janssen FJJG. Thermodynamics of gaschar reactions: first and second low analysis. Chem Eng Sci 2003;58:1003-11.

[26] Bouraoui Z, Dupont C, Jeguirim M, Limousy L, Gadiou R. CO 2 gasification of woody biomass chars: the influence of $\mathrm{K}$ and Si on char reactivity. Compt Rendus Chem 2016;19:457-65.

[27] Bridgwater AV. The technical and economic feasibility of biomass gasification for power generation. Fuel 1995;74:631-53.

[28] Schuster G, Loffler G, Weigl K, Hofbauer H. Biomass steam gasification - an extensive parametric modeling study. Bioresour Technol 2001;77:71-9.

[29] Lajili M, Limousy L, Jeguirim M. Physico-chemical properties and thermal degradation characteristics of agro pellets from olive mill by-products/sawdust blends. Fuel Process Technol 2014;126:215-21.

[30] Li CZ. Importance of volatile-char interactions during the pyrolysis and gasification of low-rank fuels - a review. Fuel 2013:112:609-23. 
[31] Jeguirim M, Kraiem N, Lajili M, Guizani C. The relationship between mineral contents, particle matter and bottom ash distribution during pellet combustion: molar balance and chemometric analysis. Environ Sci Pollut Control Ser 2017;24:9927-39.

[32] Umeki K, Yamamoto K, Yochikawa T. High temperature steam-only gasification of woody biomass. Appl Energy 2010;87:791-8.

[33] Zhou J, Chen Q, Zhao H, Cao X, Mei Q, Luo Z, et al. BiomassOxygen gasification in a high-temperature entrained-flow gasifier. Biotechnol Adv 2009;27:606-11.

[34] Qin K, Lin W, Jensen PA, Jensen AD. High-temperature entrained flow gasification of biomass. Fuel 2012;93:589-600.

[35] Mermoud F, Salvador S, van de Steen L, Golfier F. Influence of the pyrolysis heating rate on the steam gasification rate of large wood char particles. Fuel 2006;85:1473-82.

[36] Chouchene A, Jeguirim M, Trouvé G, Favre-Reguillon A, Le Buzit G. Combined process for the treatment of olive mill wastewater: adsorption on sawdust and combustion of the impregnated sawdust. Bioresour Technol 2010;101:6962-71.

[37] Guizani C, EscuderoSanz FJ, Salvador S. The gasification reactivity of high-heating-rate chars in single and mixed atmospheres of $\mathrm{H}_{2} \mathrm{O}$ and $\mathrm{CO}_{2}$. Fuel 2013;108:812-23.

[38] Vandesteene L, Tagutchou JP, EscuderoSanz FJ, Salvador S. Gasification of woodchip particles: experimental and numerical study of char-H2O, char-CO2, and char-O2 reactions. Chem Eng Sci 2011;66:4499-509.
[39] Lajili M, Guizani C, Escudero Sanz FJ, Jeguirim M. Fast pyrolysis and steam gasification of pellets prepared from olive oil mill residues. Energy 2018;150:61-8.

[40] Bouraoui Z, Jeguirim M, Guizani C, Limousy L, Dupont C, Gadiou R. Thermogravimetric study on the influence of structural, textural and chemical properties of biomass chars on $\mathrm{CO}_{2}$ gasification reactivity. Energy 2015;88:703-10.

[41] Courson C, Udron I, Swierczynski D, Petit C, Kinnemann A. Hydrogen production from biomass gasification on nickel catalysts: tests for dry reforming of methane. Catal Today 2002;76:75-86.

[42] Nilsson S, Gómez-Barea A, Fuentes-Cano D, Campoy M. Gasification kinetics of char from olive tree pruning in fluidized bed. Fuel 2014;125:192-9.

[43] Luo S, Xiao B, Hu Z, Liu S, Guan Y, Cai L. Influence of particle size on pyrolysis and gasification performance of municipal solid waste in a fixed bed reactor. Bioresour Technol 2010;101:6517-20.

[44] Inayat M, Sulaiman SA, Kumar A, Guangul FM. Effect of fuel particle size and blending ratio on syngas production and performance of co-gasification. J Mech Eng Sci 2016;10:2188-200.

[45] Feng Y, Xiao B, Georner K, Cheng G, Wang J. Influence of particle size and temperature on gasification performance in externally heated gasifier. Smart Grid Renew Energy 2011;2:158-64.

[46] Chakrabarti R, Colby JL, Schmidt LD. Effects of biomass inorganics on rhodium catalysts: I. Steam methane reforming. Appl Catal B Environ 2011;107:88-94. 